\title{
ENGENDERED EMOTIONS: GENDER AWARENESS OF TURKISH WOMEN MIRRORED THROUGH REGRETS IN THE COURSE OF LIFE
}

\author{
ŞULE TOKTAŞ \\ Department of Political Science and Public Administration, Bilkent University, Ankara, 06533 Turkey
}

\begin{abstract}
Synopsis - In this article, the results of a qualitative study on gender awareness of Turkish women mirrored through regrets in the course of life are discussed. The study composed of life history interviews and focus groups interviews with Turkish women, who were 1960-1970 graduates of various Girls' Institutes and working as schoolteachers and academics showed that the women reflect on their lives in gendered terms. The women's regrets arose mainly in relation to three domains: work, marriage and motherhood, which revealed that women separate their feelings of regret regarding marriage from the satisfaction they derive from motherhood. In the evaluations of the past, an ignored women's history surfaces within the context of modernization reforms in Turkey, which provided women the means of "standing on our own feet" without depending on men. (C) 2002 Elsevier Science Ltd. All rights reserved.
\end{abstract}

\section{INTRODUCTION}

Regret is not an uncommon response when individuals evaluate past experiences. The evaluation of past life may have a gender dimension; that is to say, one's gender may have an impact on how past experiences are perceived and dealt with. Considering that women are in a relatively more oppressed position than men in patriarchal contexts, one can posit a correlation between the regrets that women may feel when evaluating their past life and gender awareness, which might also be termed feminist consciousness or awareness of gender inequality. In this respect, women's perceptions of gender roles and their awareness of gender inequality can be traced through the nature of their regrets when reflecting on their lives. Such a framework may serve for an understanding of the consciousness developed by women, which would inherently contain their ideological position and status with respect to patriarchy.

Regret can be defined as the reminiscence of a blocked goal or past intention that a person currently wishes to have achieved but could not pursue (Lecci, Okun, \& Karoly, 1994, p. 731). It is a counterfactual emotion that results from the contrast between the

The author would like to thank Dilek Cindoğlu and Scott Spehr for helpful comments and suggestions regarding earlier versions of this manuscript. actual outcomes and the imagined alternative outcomes regarding "what might have been" (Kahneman \& Miller, 1986). Furthermore, it is associated with the desire or wish to change past thoughts, feelings, actions or accomplishments (Degenova, 1992, p. 136). Although regret has been linked with feelings of sorrow, disappointment or distress over something done or not done (Landman, 1987, p. 524), recent studies have focused on the difference between regret and other negative emotions like disappointment, in the sense that regret involves a choice that would have resulted in a better outcome, while disappointment may not always involve a consideration of a choice but rather a feeling of failure (van Dijk, Zeelenberg, \& van der Plight, 1999; Zeelenberg, 1999; Zeelenberg, van Dijk, Manstead, \& van der Plight, 2000).

Regret has been of primary concern in formal economic theories regarding investor and/or consumer choices (Kahneman \& Riepe, 1998; Loomes, 1988). Psychological studies, on the other hand, deal with regret in relation to psychological adjustment. It has been pointed out that regret affects life satisfaction (Butler, 1963) and that unachieved goals cause depressive symptoms in the sense that the more regrets recalled, the greater the psychological distress (Lecci et al., 1994; Lewis \& Borders, 1995). Reminiscence about past experience and coming to terms with it are thought to construe a way of coping with the present situation (Lata, Nakamoto, \& Deganova, 
1997). Likewise regret, although a negative emotion, may positively impact on psychological repackaging (van Dijk et al., 1999) and furthermore, may be functional as part of a learning process, since both anticipated and experienced regret may encourage one to correct his/her mistakes (Caffray \& Schneider, 2000; Zeelenberg, 1999). This is why regret may encourage goal setting and active efforts to actualize goals (Stewart \& Vandewater, 1999).

Studies on regret have addressed its various aspects. Zeelenberg (1999), for example, points out that regret is primarily a cognitive emotion because one needs to think first in order to regret. Lecci et al. (1994, p. 732) set forth the relevance of the time dimension in the construction of the self, and indicate that regret in the course of life refers to possible selves; that is, past, present and future selves redefined by the current self. Along with the distinction made by Kahneman and Tversky (1982) between regrets of omission and regrets of commission, Landman (1987, p. 526) found that people felt greater regret regarding actions taken, e.g., having switched to stock in a company that resulted in a decrease of share value than for actions not taken such as "not saying how much I love her/him" after the death of a spouse. Gilovich and Medvec (1995) find that action taken produces more immediate regret. For example, having chosen one field of study rather than another. On the other hand, actions not taken generate more regret in the long run. For example, regret associated with missed educational opportunities (Gilovich \& Medvec, 1995, p. 384).

Gender can be a mitigating factor regarding regret, as has been revealed in certain psychological studies that point to differences between men's and women's feelings of regret. Landman (1987, p. 534), in her research on American undergraduate students, found that men feel more regretful for action taken than do women. Lata et al. (1997), in their survey of college students, found that female students were more regretful than male students regarding past choices that impact their current physical appearance; the authors believe this may account for the greater prevalence of eating disorders among women in the U.S.A. compared to men. Degenova (1996), in her research on elderly people, found that both men and women wish they could have pursued more education but women were significantly more regretful in this area. Educational regret was also salient in the studies of Metha, Kinnier, and McWhirter (1989) and Lewis and Borders (1995), who also found that women regretted not having been more assertive, not having taken more risks and not having spent more time with the family.
Sexuality studies take a more encompassing gender view, yet they do not specifically address the concept of gender awareness. Dickson, Paul, Herbison, and Silva (1998) report that women regret having had sexual intercourse before age 16 more than do men. Other studies on the impact of abortion and/or sterilization practices on women emphasize the relative frequency of regret regarding these practices (Gratton, 1988; Hapugalle et al., 1989; Remez, 1991; Vieira \& Ford, 1996).

Expanding on the findings of the above-mentioned studies on regret, research needs to focus more intensely on the relationship between regret and gender, specifically regarding women and their awareness of gender inequality. Older women, who are accorded higher status in hierarchical, patriarchal societies (Kandiyoti, 1988; Özbay, 1993), may voice regret over having acted or not acted in particular ways when they were younger and may think they would do things differently were they given the chance to live their life over. In other words, being in a relatively more powerful position than when they were younger, they may be more overly critical of their younger, less powerful, less assertive selves. These regrets may serve as a reflection of a woman's growing awareness of gender inequality.

This article is based on a series of interviews carried out in 1997 with a particular group of Turkish women-schoolteachers and academics who graduated between 1960 and 1970 from what are called Girls' Institutes. All of the women involved lived at the time of the interview in Ankara. The study was designed to focus on gender awareness traced through regret regarding the women's life course. The women were questioned regarding how they perceived their gender, what they regretted most, what they would like to have changed and how they might have acted differently. The purpose of the study was to discover in what manner these regrets might be regarded as signs of a growing gender awareness.

Qualitative research techniques were assumed to be a suitable option for the implementation of an indepth and detailed study of women's gender awareness. Therefore, life history interviews and focus group interviews were used as research techniques. Stewart and Vandewater (1999) found that midlife review frequently reveals regrets about past experiences. Therefore, the questions that were asked reflected our expectations in this regard. The questions put to the women included: "When reviewing you life, have you ever said to yourself 'I wish I had done this or I had not done that?"; "Do you have any regrets?"; "Do you have any unachieved goals?"; "If the regrets that you have were to have 
been resolved, then, how would your life have been today?"; "If you had your life to live over again, what would you do differently?"

In total, 32 women were interviewed. Thirteen of the women were academics working at a university Faculty of Vocational Education and nineteen of them were schoolteachers working at various Girls' Technical Education High Schools. Out of the 32 women, five were single and childless, two were married without children, and 25 were married with children. Fourteen women were trained in Sewing, six in Embroidery, five in Child Development, four in Painting, two in Handicrafts, and one in Family Economics and Nutrition. The women were 17 or 18 years of age when they graduated from the Girls' Institutes. They all then went on to complete university studies, in some cases, up to doctoral level. At the time of the study, they were between 42 and 59 years of age. All the women were in paid work, except for two schoolteachers who had recently retired. Three focus groups were formed of five, six and seven participants, respectively. The first group consisted of academics, while the second and third groups consisted of schoolteachers. All of these women had married and had borne children. Life history interviews were conducted with the remaining 14 women. Most of the women came from urban backgrounds and middle socio-economic status.

\section{THE CRYSTALLIZATION OF GENDER ROLES: THE GIRLS' INSTITUTES IN TURKEY}

After the abolition of the Ottoman Empire and the foundation of modern Turkey in 1923, social, legal, cultural, and educational reforms designed to elevate young Turkey to the level of Western European civilizations were initiated. These Republican reforms were the foundation for a cultural revolution, aimed at turning a traditional society into a modern one (Abadan-Unat, 1991). The state replaced the Arabic alphabet with the Latin alphabet; closed down all the free schools of religion and replaced them with secular, scientific and co-educational schools under the Ministry of Education; banned religious brotherhood activities; restricted the wearing of the fez and supported Western codes of dressing for both women and men; and replaced the old Ottoman Legal Code with one based on the Civil Code of Switzerland. This new code was designed to help introduce rules of Western modes of living (Abadan-Unat, 1991). Banning polygamy and giving women property as well as inheritance rights were some of the radical changes that the new Code introduced.
The aim of the newly founded state was the construction of a modern society. In the implementation of modernization policies, women were to take on an instrumental role (Kadıoğlu, 1994; Kandiyoti, 1987). The Republican reforms signaled the new positioning of the state vis-á-vis women (Kandiyoti, 1989, p. 126). Women, as homemakers and as mothers who would raise the future generations of citizens according to the ideals of the state, were to disseminate the values of the Republic and to construct a modern family (Kadığlu, 1994, p. 650). However, this was not a means of confining women to the domestic sphere; in addition to their roles in the household, women were to take part in the public sphere by way of education and work (Kadığlu, 1994, p. 652). Yet, in this society, there still existed the constraints of traditional gender values. These existed more among non-elite families, and were reflected most fundamentally in education. Among the elite where these values were overridden by Republican ideals, women in significant numbers were able to receive tertiary education (Abadan-Unat, 1991, p. 182). Thus, when compared to the West, from the early days of the Republic, there was a significantly high ratio of women in higher education (Acar, 1994). Yet, since these values were not equally shared by the masses, women's education beyond elite circles remained very limited (Acar, 1994; Öncü, 1979). This was the case with respect to secondary education of girls in the countryside (Abadan-Unat, 1991, p.183). At this point, the Girls' Institutes entered the scene as part of the secondary education system.

The Girls' Institutes were single-sex educational institutes at high school level where daily contact with the opposite sex was curtailed. In the Girls' Institutes, students were trained to be "good housewives and mothers" and were instructed in "feminine fields" like sewing, embroidery, handicrafts and home economics (Ministry of National Education General Directorate of Girls' Technical Education, 1992, 1993, 1996). This education program, having a traditional outlook, seems to be what most attracted many of the respondents' families, who were not opposed to exposing their daughters to the public sphere through education in single-sex schools. The Girls' Institutes, in a sense, seem to have performed both functional and symbolic roles for the implementation of the state's educational reforms, which called upon women to be educated in secular and modern schools. Through this, traditional biases like "girl children should not be educated" were to be ended. In relation to this feature, it has to be noted that the Girls' Institutes were the schools where gender roles crystallized as part of the moderniza- 
tion of traditional concepts of femininity. Women who did the work of mothering and housekeeping and transferred their know-how from generation to generation for many centuries were now being taught in public institutions. The state, in effect, awarded women who filled traditional female roles with a diploma.

\section{PARADOX AND RESOLUTION: "TO STAND ON OUR OWN FEET"}

In the interviews, the respondents revealed two paradoxes between the state's vision of training women in how to be "good mothers and housewives" in the Girls' Institutes and the wishes of the graduates themselves. First, some of the graduates did not become housewives exclusively, but instead worked in the public sphere. Second, and more interestingly, among the graduates who chose to work outside their homes, some did not marry and become mothers as anticipated, but remained single.

The value attributed to education and work by the families of the respondents and the availability of work opportunities in state offices for secondary school leavers in the 1960s help explain why the graduates of the Girls' Institutes did not become housewives exclusively but worked in the public sphere.

All of the respondents emphasized the fact that their families encouraged them to get an education in the Girls' Institutes, which would provide a means of economic independence and self-sufficiency and enable them to "stand on our own feet." Some of the women specified that their mothers were more encouraging than their fathers. The mothers' emphasis on their daughters' education seemed to have resulted from the mothers' own oppression in their nuclear or extended families. The mothers did not have the means of escaping from oppression because they were economically and socially dependent on familial relations. However, their daughters had a chance to emancipate themselves by way of education and work. For this frustrated ideal to be realized by their daughters, the mothers refrained from teaching their daughters domestic skills and avoided the promotion of values that prioritized domesticity and marriage. In this respect, the women's mothers instilled their daughters with a sense of gender awareness emanating from the mothers' unachieved goals.

For all her children especially for her daughters, my mother wanted education... Especially my mother wanted a lot. My father wanted it, too. My father did not reveal it but my mother did... For the aspects of economic freedom and culture. . She was aware that certain things could be learned through education. She lived in the period of the Republic, I mean, during the war of independence. She was conscious of the things that education enables. Teachers made great effort in literacy campaigns. In the old times of district schools, she had a teacher. She talked about her all the time. Her love for that teacher influenced us. She said, 'If I have children, if I have a daughter, I will make her a teacher.' In these times, a teacher was treated with respect. A teacher was treated with tenderness... Apparently it was an unachieved goal [for the mother]. My mother wanted us to get an education [since she was unable to]. (From life history interview)

In the $1960 \mathrm{~s}$, as a result of state recruitment policies, women could become civil servants in post offices or banks after graduating from Girls' Institutes. If they continued their education at Girls' Vocational Teacher Training College, they could become Institute teachers, which was a very prestigious vocation at the time for this group of women. They could also make good marriages (with men of a higher socio-economic status) and if they were not working in public offices, they could earn their living through the skills taught at school such as sewing, in the event of critical life conditions (divorce, the death of husbands or parents). Hence, some of the women defined vocational education as a "golden bracelet." Just as Turkish women sell their golden bracelets in times of economic need, vocational education, like a golden bracelet, is thought to secure for women a livelihood independent of any other person within or outside marriage.

For us [it was important] to stand on our own feet; because it is unpredictable how good a marriage turns out to be, what life conditions will be. For that reason, we needed to attain a vocation; they [the parents] used to say, 'No matter if you wish to work or not, you have to have a vocation.'... You can lose a husband, there can be a bad marriage, anything may happen. The future is unknown. (From life history interview)

The respondents mentioned mainly the positive aspects of working. Working was seen as crucial for economic independence, social security, social productivity, social life outside the family, a respected social status, and more say in family affairs. On the whole, the women never thought of quitting their jobs. Rather, to be able to work, some of them 
struggled with their husbands who resisted their wives' working.

The notion of "standing on our own feet" highlights another paradoxical finding, which is the significance of remaining single for working women who graduated from Girls' Institutes. In addition to this, the women's expectations with regard to husbands explain their remaining single. Single women thought a husband should be wealthy, older, selfsufficient, of a higher education, respectful of his wife, but most importantly, he should have a liberal attitude towards his wife working. Besides not meeting men with the specified qualities, the perception of marriage as incompatible with work was another reason why some of the respondents remained single.

I always gave priority to my profession. Marriage was like an obstacle to me. Of course, I realized that was not completely so because I have married friends who work. But I realized this at a late age. I did not accept it before. Still, I think that if a person wants to progress in her profession, I mean, of course marriage is a very good thing but it can be an obstacle. (From life history interview)

The single respondents did not devalue motherhood as much as they devalued marriage, however. Women question the sacrifices involved in marriage but not the image of devoted motherhood.

I would hardly have found a reason to put up with a man in the case [of marrying but not having children]. I give precedence to being a mother... First of all, I wish that I had had many children. And I wish I had married a man with a good enough economic situation to raise those children. I wish I had had servants to do the housework. And I wish that my children had a good education. I love big families. But for this, I would have had to get married the year I finished school... I would have been a wonderful mother but I would not have had a career, because I would have wanted to raise my children myself. I could have not come to school after leaving them with child care workers. If my children had gone to school on their own, I could not have been teaching here because I would have had worries about home. I value human beings very highly. (From life history interview)

In the study, regrets in relation to past experiences arose mainly on three areas: work, marriage and motherhood, which will be elaborated in the following sections.

\section{REGRETS ABOUT WORK}

The issue of regrets in the course of life never arose in the sense of regretting working, but of not being able to pursue the ideal career.

Some of the women schoolteachers stated that they would have preferred to attend a normal high school and then a university and become lawyers, pharmacists or physicians, particularly pediatricians. Although teaching seems to have been a very prestigious and high-income profession in the 1960s for this group of women, in today's Turkey, other professions are more valued. When asked about what their life would be like if they had entered these professions, respondents said that their life would be the same with the difference that they would be earning more money and would have a higher social status. Nevertheless, schoolteachers on the whole did not regret being teachers, because of the public acknowledgment of teaching as one of the most suitable professions for women. Schoolteachers, like students, have longer mid-term and summer vacations and more flexible schedules, not incompatible with the women's domestic duties.

I think that teaching is one of the most appropriate vocations for girls... Our high school requires a full working day but other schools half a day. At least she can do her housework and not neglect her work. She can raise her children. There are summer holidays. There are midterm holidays. (From life history interview)

Women academics seemed to be more careeroriented than schoolteachers. About the positive aspects of their job, they did not emphasize the flexible working hours of their profession but the social status and the promotion opportunities.

Some of the academic respondents stated that they wanted to be in another area more compatible with their interests. Academic women who specialized in Painting or Sewing did not regret having entered the Institutes but wished they had attended a university Faculty of Applied Fine Arts, the other available university choice for Institute graduates besides Girls' Vocational Teacher Training College-in order to become artists or fashion photographers. Some of the academics and schoolteachers wished they had studied at the Faculty of Applied Fine Arts because they did not want to teach. This may be due to the devalued perception of teaching, mostly the domain 
of women. The Faculty of Applied Fine Arts may also be perceived as a gender neutral place, more challenging than the Girls' Vocational Teacher Training College, which trains girl students in feminine skills. Additionally, many of the women regretted not being more creative in handicrafts, an attribute that they interpreted as a key to success, which also arose in the interviews with the academics. Finally, academics expressed regret at not having utilized the opportunity of doctoral study abroad.

The common theme in these interviews and group discussions is that the autonomy that emanates from work is very important for both academics and schoolteachers.

If I had been a housewife, if I had been an Institute graduate and had become a housewife, I would have had many regrets now. There would have been the degradation of not going to school. I would not have economic independence. Like certain things my mother cautioned me about. (From life history interview)

This study confirms previous research on regrets pointing out that women frequently have education and career regrets (Degenova, 1996; Lewis \& Borders, 1995; Metha et al., 1989). In relation to work, some of the respondents wish that they could have become pediatricians, pharmacists, architects, lawyers, artists, fashion photographers, etc. This may be due to the wish to secure higher status and higher income than teaching or academia afford. Drawing on the point that Lecci et al. (1994, p. 732) set forth about the redefinition of the current self by time variance through regrets in the course of life, it can be argued that women evaluate their past with regard to their current values. These values may or may not have changed since their youth. The prestige attributed to work is relatively static, yet the type of work correlates with different levels of prestige.

In this regard, there may be a link between the paradoxes relevant to the Girls' Institutes and graduates. Work is a very deeply-rooted value among these women. The Republican reforms enabled women the right to function outside the traditional domestic sphere (Kandiyoti, 1993). Turkish women adapted to the reforms willingly, and promoted the modernist values (Öncü, 1979). My respondents seem to question the extent of that right, and express regret that they did not have the opportunity to develop their careers further. The state, in pursuing the project of modernization, seems to have been successful in convincing women (and their families) to access the public sphere by way of work and education. However, the respondents' regrets about not having achieved more assertive and challenging roles reveal that women developed a more advanced and intense form of gender awareness than the instrumental approach that the state has incorporated.

\section{REGRETS ABOUT MARRIAGE}

Another frequent regret was marriage, especially in relation to independence. Some of the women regretted marrying at an early age.

I wish I had married at a later age. The school environment was very good and I did not want to take on such a responsibility. I wish I had remained single a little longer. (From life history interview)

Some of the women wished they had married different men who would were more tolerant and liberal than their husbands.

My regret is that I accepted my husband according to my father's wishes. I was very young. I was sixteen. . . I am also a religious person. I love God, but no further [i.e. fundamentalism]. I thought that, since I did not know religion exactly, 'You do what the father says.' I mean, I thought that this was unquestionable. But Islam is not like that at all. I realized this after I read the Quran. The rights of women are very important. A woman gets married only if she wants to. If I had known this, I would not have married him. . . There could be another person. He could be more rational, more reasonable...there is wide age gap between us. My husband is eight years older than me. Maybe it would also be different [if the age gap did not exist]. I do not know... But you see these are the regrets. I wonder how it would be if I were a man. Would I be more at ease? Men are freer... But to be a mother is a very good feeling. I am very glad about my children. I have three sons. I gave birth to the last child with the hope that it may be a girl but unfortunately...(From focus group)

Respondents who were married and had children never regretted having had children, but had doubts about the timing of marriage or the choice of mate.

I have regrets about mate preference. No, I never said I should not have married at all. As I said, the satisfaction I gained from marriage, from my children is numerous. But I wish I had not married him, I wish I had chosen someone more 
suitable... I see my marriage as the biggest mistake of my life. (From life history interview)

I still believe that I got married too early. This is why I tell my daughter not to marry early... I mean, I didn't experience any negative consequences but being raised as a girl child, although we were in a boarding school, before getting engaged, I always wanted to be on my own at least for four or five years...no matter how democratic, marriages have the aspect of dependence. . I I have a very independent personality. . That is why I always thought of an autonomous, liberal life... That is why it was an early marriage for me. (From life history interview)

The respondents' gender awareness is most clear in their regrets about marriage and their open critique of masculinity. Respondents regret having married oppressive men, or wish to have married men who care and respect their wives. The wish to have married at a later age may have roots in the perception of marriage as an institution, which is perceived to be oppressive. Despite this, women do not regret marrying due to the satisfactions of motherhood.

\section{REGRETS ABOUT MOTHERHOOD}

Respondents with one child regretted most not having had another child. Mothers regretted not spending more time with their children due to work, though they never thought of quitting work.

Regret about not having had children was widely expressed by the single respondents. One of the respondents explained her desire to have become a mother with the sacrifice she would have made for that:

No, I do not have any regrets. Only being a mother... That, that is a sinking regret. I would have liked to become a mother. I would have quit working. I wish, I mean, I thought, there were others with the same characteristics who wanted to marry me but wanted me not to work. I wish I had accepted their offers because I could become a mother then. This rankled me. It still rankles. (From life history interview)

I wish I had had children because I love children. I satisfy this need with my students. I love my students. Maybe because I feel this way, marriage became useless for me. There are other children around. This is selfishness, of course. This is a selfish thought. To have a child, why is it necessary to suffer the other consequences of marriage? This is selfishness. This is wrong. This is absolutely wrong. (From life history interview)

In Turkey, motherhood is a social institution which is strictly confined to marriage (Özbay, 1995, p. 155). This explains why the married women avoided remaining single in that they value motherhood so highly. The women who had only one child regretted not having had a second. The single academics regretted not having married for the same reason. These regrets illustrate that marriage in itself was never an ideal for either married or unmarried women. These women seem to make a clear distinction between motherhood and marriage. Wage labor employment seems to have played an important role in this distinction. Women who are financially independent have the option of remaining mothers while dissolving their marriages even if this option is rarely exercised. Respondents' regrets clarify the perception of marriage by unmarried women as an institution of sacrifice, and by married women as an institution of constraint and dependence. Motherhood, not marriage per se, was seen as the main focus of the private sphere, which is why women value that sphere. These regrets illustrate the women's expectations, as the following statements demonstrate:

Doctoral education and diapers are very important. You may not have cleaned the house, but you should not neglect those two. (From focus group)

Freud has a saying with which I agree a lot. 'Living is for love and work.' This is very important for me. If the meaning of life rests in love, it also rests in working, being productive and being useful. (From life history interview)

The respondents apparently believe that the satisfaction gained through work and motherhood makes up for their oppression as women. In other words, although they seem to be aware of their gender and of gender inequalities, the respondents remained within the confines of their prescribed gender and social roles. They think that they are fortunate when compared to the generation of their mothers. In this sense, they have a progressive understanding of history.

\section{CONCLUSION}

My study demonstrates that the content and meaning of regret have a gender base. Thus, while both men and women may express regret about missed educational 
opportunities (Degenova, 1992), opportunity has a different meaning for my respondents. The Turkish women in this study took advantage of the opportunities provided by the Kemalist reforms which enabled them to "stand on our own feet" without depending on men. The study then supports the proposition that the issue of regret should be analysed within the historical, cultural and social context of individual subjectivities. That is, individuals are always subject to such contextual factors, and their emotional responses, such as feelings of regret, reflect that.

Moreover, this qualitative study showed that women reflect on their lives in gendered terms. The women's regrets, which arose mainly in relation to three domains: work, marriage and motherhood, are instrumental in tracing women's awareness of gender inequality. Women's regrets are also useful measures of gender construction. This was illustrated in this study by revealing that many of the respondents separate their feelings of regret regarding marriage from the satisfaction they desire for motherhood. The women's wage labor facilitated their ability to make that distinction. This study made it clear that women are conscious of their positioning in the gender order and that they question it.

\section{REFERENCES}

Abadan-Unat, Nermin (1991). The impact of legal and educational reforms on Turkish women. In Nikki R. Keddie \& Beth Baron (Eds.), Women in middle eastern history: Boundaries in sex and gender (pp. 177-194). London: Yale University Press.

Acar, Feride (1994). Women and higher education in Turkey: A gold bracelet for women. In Suzanne Lie, Lynda Malik, \& Duncan Harris (Eds.), The gender gap in higher education (pp. 160-170). London: Kogan Page.

Butler, Robert N. (1963). The life review: An interpretation of reminiscence in the aged. Psychiatry 26, 65-76.

Caffray, Christine M., \& Schneider, Sandra L. (2000). Why do they do it? Affective motivators in adolescents' decisions to participate in risk behaviours. Cognition and Emotion 14(4), 543-577.

Degenova, Mary K. (1992). If you had your life to live over again: What would you do differently? International Journal of Aging and Human Development 34(2), $135-143$.

Degenova, Mary K. (1996). Regret in later life. Journal of Women and Aging 8(2), 75-85.

Dickson, Nigel, Paul, Charlotte, Herbison, Peter, \& Silva, Phil (1998). First sexual intercourse: Age, coercion, and later regrets reported by a birth cohort. BMJ, British Medical Journal 316(7124), 29-34.

Gilovich, Thomas, \& Medvec, Victoria H. (1995). The experience of regret: What, when, and why. Psychological Review 102(2), 379-395.

Gratton, Nicole M. (1988). Sterilization regret among women in metropolitan Montreal. Family Planning Perspectives 20(5), 222-227.
Hapugalle, Dennis, Janowitz, Barbara, Weir, Sharon, Covington, Deborah L., Wilkens, Lynne, \& Aluvihare, Celene (1989). Sterilization regret in Sri Lanka: A retrospective study. International Family Planning Perspectives 15(1), $22-28$

Kadıŏlu, Ayşe (1994). Women's subordination in Turkey: Is Islam really the villain? Middle East Journal 48(4), 645-660.

Kahneman, Daniel, \& Miller, Dale T. (1986). Norm theory: Comparing reality to its alternatives. Psychological Review 93, 136-153.

Kahneman, Daniel, \& Riepe, Mark W. (1998). Aspects of investor psychology. Journal of Portfolio Management 24(4), 52-66.

Kahneman, Daniel, \& Tversky, Amos (1982). The simulation heuristic. In Daniel Kahneman, Paul Slovic, \& Amos Tversky (Eds.), Judgement under uncertainty: Heuristics and biases (pp. 201-208). New York: Cambridge University Press.

Kandiyoti, Deniz (1987). Emancipated but unliberated? Reflections on the Turkish case. Feminist Studies 13(2), 317-338.

Kandiyoti, Deniz (1988). Bargaining with patriarchy. Gender and Society 2(3), 274-290.

Kandiyoti, Deniz (1989). Women and the Turkish state: Political actors or symbolic pawns? In Nira Yuval-Davis, \& Floya Anthias (Eds.), Women-Nation-State (pp. 126-149). London: MacMillan.

Kandiyoti, Deniz (1993). Ataerkil örüntüler: Türk toplumunda erkek egemenliğinin çözümlenmesine yönelik notlar (Patriarchal patterns: Notes for the analysis of male domination in the Turkish society). In Şirin Tekeli (Ed.), 1980'ler Türkiye’sinde kadın bakış açısından kadinlar (Women from woman's perspective in the 1980s) (pp. 367-382). Istanbul: İletişim.

Landman, Janet (1987). The feeling of regret and elation following action and inaction: Affective responses to positive versus negative outcomes. Personality and Social Psychology Bulletin 13(4), 524-536.

Lata, Jeffrey L., Nakamoto, Mindy J., \& Degenova, Mary K. (1997). Regrets of college students: Implications for outlook on life. College Student Journal 31(4), 480-490.

Lecci, Len, Okun, Morris A., \& Karoly, Paul (1994). Life regrets and current goals as predictors of psychological adjustment. Journal of Personality and Social Psychology 66(4), 731-741.

Lewis, Virginia G., \& Borders, L. Dianne (1995). Life satisfaction of single middle-aged professional women. Journal of Counseling and Development 74(1), 94-101.

Loomes, Graham (1988). Further evidence of the impact of regret and disappointment in choice under uncertainty. Economica 55(217), 47-62.

Metha, Arlene, Kinnier, Richard T., \& McWhirter, Ellen H. (1989). A pilot study on the regrets and priorities of women. Psychology of Women Quarterly 13, 167-174.

Ministry of National Education General Directorate of Girls' Technical Education (1992). İkibinli y1llar öncesinde Türkiye'de kadın eğitimi [Women's education before the 2000s], Ankara.

Ministry of National Education General Directorate of Girls' Technical Education (1993). Kız teknik öğretimde geliş meler I-II [The developments in women's technical education I-II], Ankara.

Ministry of National Education General Directorate of Girls' Technical Education (1996). 1865-1996: 131 Y1l [1865-1996: 131 years], Ankara. 
Öncü, Ayşe (1979). Uzman mesleklerde Türk kadını (Turkish women in the professions). In Nermin Abadan-Unat (Ed.), Türk toplumunda kadın (Woman in Turkish society) (pp. 271-286). Ankara: Association of Turkish Social Sciences.

Özbay, Ferhunde (1993). Kadınların eviçi ve evdışı uğraşlarındaki değişme (The changes in women's domestic and public roles). In Şirin Tekeli (Ed.), 1980'ler Türkiye sinde kadın bakış açısından kadınlar (Women from woman's perspective in the 1980s) (pp. 129-158). Istanbul: İletișim.

Özbay, Ferhunde (1995). Kadının statüsü ve doğurganlık (Woman's status and fertility). In Necla Arat (Ed.), Türkiye'de kadın olgusu (Woman issue in Turkey) (pp. 151-167). Istanbul: Say.

Remez, Lisa (1991). Women sterilized before age 25 are most likely to regret their decision. Family Planning Perspectives 23(5), 236-238.

Stewart, Abigail J., \& Vandewater, Elizabeth A. (1999). If I had it to do over again: Midlife review, midcourse cor- rections, and women's well-being in midlife. Journal of Personality and Social Psychology 76(2), 270-283.

van Dijk, Wilco W., Zeelenberg, Marcel, \& van der Plight, Joop (1999). Not having what you want versus having what you do not want: The impact of type of negative outcome on the experience of disappointment and related emotions. Cognition and Emotion 13(2), 129-148.

Vieira, Elizabeth M., \& Ford, Nicholas J. (1996). Regret after female sterilization among low-income women in Sao Paulo, Brazil. Family Planning Perspectives 28(2), 32-39.

Zeelenberg, Marcel (1999). The use of crying over spilled milk: A note on the rationality and functionality of regret. Philosophical Psychology 12(3), 325-341.

Zeelenberg, Marcel, van Dijk, Wilco W., Manstead, Anthony S.R., \& van der Pligt, Joop (2000). On bad decisions and disconfirmed expectancies: The psychology of regret and disappointment. Cognition and Emotion 14(4), 521-541. 